
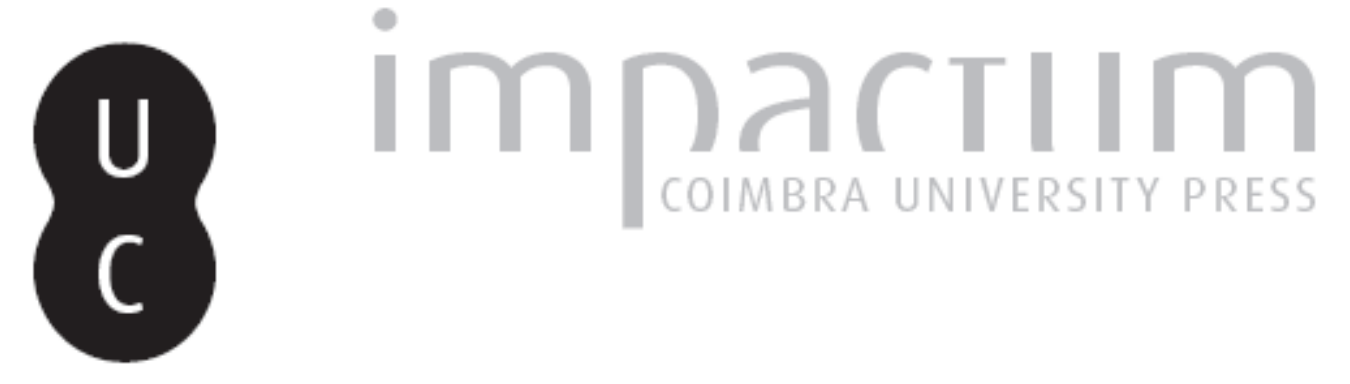

\title{
A little more on Galileo and the mixed sciences
}

Autor(es): $\quad$ Nascimento, Carlos Arthur Ribeiro do Publicado por: $\begin{aligned} & \text { Faculdade de Letras da Universidade de Coimbra, Instituto de Estudos } \\ & \text { Filosóficos }\end{aligned}$

URL

persistente:

DOI: $\quad$ DOl:http://dx.doi.org/10.14195/0872-0851_44_1

Accessed : $\quad$ 26-Apr-2023 02:38:10

A navegação consulta e descarregamento dos títulos inseridos nas Bibliotecas Digitais UC Digitalis, UC Pombalina e UC Impactum, pressupõem a aceitação plena e sem reservas dos Termos e Condições de Uso destas Bibliotecas Digitais, disponíveis em https://digitalis.uc.pt/pt-pt/termos.

Conforme exposto nos referidos Termos e Condições de Uso, o descarregamento de títulos de acesso restrito requer uma licença válida de autorização devendo o utilizador aceder ao(s) documento(s) a partir de um endereço de IP da instituição detentora da supramencionada licença.

Ao utilizador é apenas permitido o descarregamento para uso pessoal, pelo que o emprego do(s) título(s) descarregado(s) para outro fim, designadamente comercial, carece de autorização do respetivo autor ou editor da obra.

Na medida em que todas as obras da UC Digitalis se encontram protegidas pelo Código do Direito de Autor e Direitos Conexos e demais legislação aplicável, toda a cópia, parcial ou total, deste documento, nos casos em que é legalmente admitida, deverá conter ou fazer-se acompanhar por este aviso.

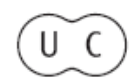




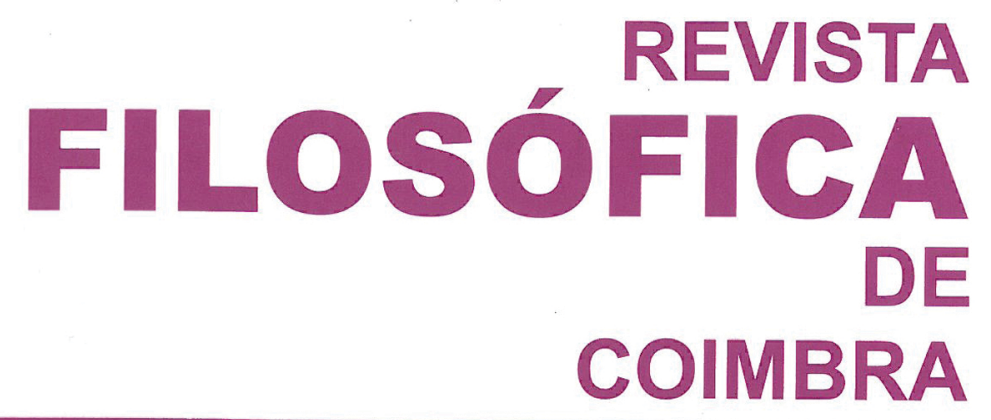

vol. 22 - número 44 - outubro 2013

vol. 22 - número 44 - outubro 2013 Fundação Eng. António de Almeida

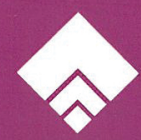




\title{
A LITTLE MORE ON GALILEO AND THE MIXED SCIENCES
}

\author{
CARLOS ARTHUR RIBEIRO DO NASCIMENTO*
}

\begin{abstract}
In the second half of the 1960s, scholars became more concerned with the epistemic status of the sciences called "the more physical of the mathematics" by Aristotle, or "mixed sciences" by the Latin Avicenna and "middle sciences" by Aquinas. The list of such sciences comprehended astronomy, optics and harmonics (music), whereas mechanics was thought to be the poor man's counterpart to those. To such a list, Avicenna adds the science of the moving sphere and the science of the weights, additions maintained by Aquinas too. One of the main interests in the study of the mixed sciences was its relation with the Galilean physics. In reality, there are but a few explicit references to these sciences by Galileo. Nevertheless, one passage of the Discorsi, preceding the experience with the inclined plane, mentions the technical definition of the middle sciences and enumerates the main ones. Galileo is not interested in the epistemic issues that had kept thinkers busy as regards these sciences for centuries. Rather, he wants to establish a foundation to his definition of accelerated uniform movement and his postulate about inclined planes of the same height. These concerns kept him busy since the beginning of the study of the accelerated uniform movement in the Discorsi.
\end{abstract}

Key-words: Mixed sciences; Galileo; Aristotle; Thomas Aquinas; Movement

Resumo: Na segunda metade da década de sessenta do século XX, começou a ser dada um pouco mais de atenção à situação epistêmica das ciências que Aristóteles denomina "as mais físicas das matemáticas", o Avicena Latino "ciências mistas" e Tomás de Aquino "ciências intermediárias". A lista de tais ciências compreendia a astronomia, a ótica, e a harmônica (música), sendo a mecânica uma espécie de prima pobre. A estas Avicena acrescenta a ciência da esfera em movimento e a ciência

* Prof. UNICAMP and PUC/SP. I earnestly thank Mrs. Lavinia Silvares for the revision of my text. I also thank Dr. Pich for calling my attention to the text of Duns Scotus cited in p. 6 as well as to those of Pecham and John of Reading cited in note 11. 
dos pesos, acréscimos estes mantidos por Tomás. Um dos principais interesses no estudo das ciências mistas foi sua relação com a física galileana. Na realidade, não há muitas referências explícitas a estas ciências da parte de Galileu. No entanto, uma passagem dos Discorsi, que precede a experiência com o plano inclinado, menciona a definição técnica das ciências intermediárias e enumera as principais. Galileu não está interessado nos problemas epistêmicos que ocuparam os estudiosos no que se refere a estas ciências durante séculos, mas em fundamentar sua definição do movimento uniformemente acelerado e seu postulado sobre planos inclinados de mesma altura. Preocupações estas que o ocupam desde a abertura do estudo sobre o movimento uniformemente acelerado nos Discorsi.

Palavras-chave: Ciências Mistas; Galileu; Aristóteles; Tomás de Aquino; Movimento.

In his contribution to the volume Method and Order in Renaissance Philosophy of Nature, "Galileo and the Mixed Sciences", W. Roy Laird (Laird 1997, 253-270), after sketching the methodological tradition of the mixed sciences and pointing out its main concerns and conclusions, attempts to show how discouraging it would have appeared to anyone setting out to found a new demonstrative mixed science. As to this last step of his article, Laird points out the limited extent of Galileo's explicit reference to the tradition of the mixed sciences in his early compilation from Jesuit sources on foreknowledge and demonstration. He also shows how little Galileo was concerned with the problems that occupied the Aristotelian commentators, namely the justification of the legitimacy of the application of mathematics to physics and the kind of certitude and evidence possible to be attained by the mixed sciences. Arriving at Galileo's concerns, Laird quotes his declaration:

I shall adduce proofs that are less mathematical and more physical; and I shall use assumptions that are clearer and obvious to the senses than those which Archimedes embraced.

This claim, of the early Dialogue on Motion, holds also for the subsequent periods, as Laird shows in his essay.

It is in this context that Laird comes to the well known passage of the Discourses containing perhaps the most important reference of Galileo to the mixed sciences, in the opening dialogue to the experience with the inclined plane. Laird goes on, commenting on the role played by this experience as establishing the mathematical and physical principle of all the science of uniform accelerated motion, viz., that this movement is one in which equal moments of swiftness are added in equal times. 
What I would like to add is that this purpose aimed by Galileo is not restricted to this passage, but includes also the opening passage of the study of the uniform accelerated motion. Indeed, since this beginning, the first concern of Galileo is to present a definition of the uniform accelerated motion which is used by nature; he even pretends that his definition agrees with the essence of natural accelerated motion. Galileo then goes on to present the main reason which had led him to be confident that he arrived at the formulation of a definition of this kind. This reason is briefly presented:

What the natural experiments present to the senses appear as corresponding to the properties demonstrated after and congruent with them.

The scheme supposed by Galileo seems to be the following: certain properties observed in the natural accelerated movement ${ }^{1}$ correspond to those demonstrated by the proposed definition and can be justified by means of this one (Wallace 1992, 270-273; 284-285). This shows that the definition truly expresses what essentially characterize the uniform accelerated motion, as found in nature. Galileo's justifying scheme seems to consist of a first step in which certain properties of the natural accelerated motion are observed; these properties are supposed to be explained by a certain definition of the movement in question. This supposition changes in certitude as some properties can be deduced from the definition, which agree with those observed.

After the presentation of this main reason, Galileo adds another justification: we have to consider "the use and disposition of nature in all its other works, in the exercise of which it has used to employ the most proximate, simplest and easiest means". This axiom is illustrated by the example of the kind of swimming of fishes and the flying of birds. Indeed, no one will believe that there is a simpler and easier manner to do it than that one employed, by natural instinct, respectively by fishes and birds. It follows the application of this axiom to the case of a stone's free fall, starting from quietness. In this case we have to suppose that the additions of velocity are made "by the simplest and obvious reason to anyone". If we observe well, there is no addition simpler than that which always adds in the same manner. This is what is observed in the greatest affinity of movement with time. Indeed, regularity and uniformity of movement is defined by regularity of times and spaces: we call a translation regular, when in equal times, equal spaces are traversed. So, we can perceive that the additions of celerity, made in the simplest manner, are those that arrive by the same equalities of

${ }^{1}$ We can reasonably suppose that these properties are from the type of the law of odd numbers, of the square of time, of the double distance and of the semi-parabolic trajectory. 
time. We will then realize that "a movement is uniformly and continuously accelerated in the same way, when in any equal times, are added equal additions of celerity". So, "it seems in no manner dissonant of right reason if we consider that the intensification of velocity occurs accordingly with the extension of time". Galileo, then, repeats the definition of the movement of which he is going to deal:

"I call regular and uniform accelerated motion, that one which starting from quietness, adds to itself, in equal times, equal moments of celerity" 2 .

In this second justification of the definition of uniform accelerated motion, Galileo makes recourse to something very different from his main reason. Here, it is the axiom of simplicity, understood as an ontological law, that is used: nature usually employs in its works the nearest, simplest and easiest means. But the nearest, simplest and easiest way to make additions of velocity occurs in function of the time elapsed. Then, the uniform accelerated motion is that in which, in equal times, there are equal additions of velocity. This definition is, at last, evident - the additions of velocity occur by the simplest and obvious reason to anyone; they are not dissonant of right reason - since they occur in a way that is only a particular instance of the general way of the operation of nature ${ }^{3}$.

The first way of confirming the proposed definition of uniform accelerated motion is exemplified in the experience with the inclined plane as can be seen in the introductory dialogue of the experience.

Simplicius agrees that, presupposing the definition, the theorems demonstrated by Galileo, and presented by Salviati, will follow. But, who warrants that the proposed definition is a real one (of something in nature) and not only a simple convention, an arbitrary postulate or, at best, a nominal definition, the explanation of a term? It is at this point that Salviati gives an answer to Simplicius with reference to the traditional definition of the middle sciences (sciences which apply mathematical demonstrations to

2 This passage of the second justification of the definition of uniform accelerated motion, mainly in the final part, which comes immediately before the explicit presentation of the definition, has reminiscences of the vocabulary of "intention and remission of forms". Cf. Clagett 1951, 251-253.

3 Galileo himself says that his definition of the uniform accelerated motion is the result of repeated mental efforts (quod, tandem post diuturnas mentis agitationes repperisse confidimus. Discorsi. Vol. VIII, 197, lin. 13-14). It is known how Galileo defined at first wrongly the uniform accelerated motion in function of the space traversed. It is possible to make these facts compatible with the affirmation that the definition, in function of the time elapsed, is given by "the simplest reason and most obvious to anyone" (simplicissima atque omnibus magis obvia ratione) with the scholastic distinction between principles evident by themselves to anyone and to the experts (cf. Thomas Aquinas, Summa Theologiae, $\mathrm{I}^{\mathrm{a}}$, q. 2, a. 1). 
natural conclusions), enumerates the best known by the names of their practitioners (opticians, astronomers, engineers, acousticians and others) and says that "these ones confirm with sensible experiences their principles, which are the foundations of all the subsequent structure". This is the reason why it is not superfluous to speak largely "about this primary and greatest foundation upon which rests the huge construction of infinite conclusions". Then, the experience with the inclined plane is described, and it assures that the acceleration of anything heavy in free fall varies in the mentioned proportion, viz., that the space traversed is proportional to the square of the time elapsed.

It seems that Galileo is recalling the two types of demonstration mentioned by Aristotle, the demonstration quia and propter quid (Posterior Analitics, I, Chap. 13). As Marcel Clavelin has pointed out, in the first type "one begins reasoning ex suppositione, that is, postulating the principle or the principles able to render account of the effects; then, it will be the evidencing of a necessary connection between these principles (or causes) and the effects (and here experience will play its role) which will permit to change the initial suppositions in truths" (Clavelin 1986, 41). The second type is akin to the demonstration propter quid, as it renders the cause or reason. Here, the axiom of simplicity builds the foundation of the proposed definition.

It is also worth mentioning that Galileo establishes his principle that "the degrees of velocity acquired by the same mobile in planes with different inclination are equal, when the heights of these planes are the same" (Galilei, Discorsi, v. VIII, 205-207) with an experience. But, this one enables to see directly what is enunciated by the principle, and Sagredo argues that this experiment is almost equivalent to a demonstration (Galilei, Discorsi, v. VIII, 206-207).

The three ways to establish a principle, used by Galileo, were perhaps used mainly in optics, and this would be the reason why Galileo places this science first in the enumeration of the mixed sciences ${ }^{4}$. They are already associated by Roger Bacon in his Treatise of the Multiplication of the Species, in the study of reflection and refraction. Bacon, indeed, mentions in this context three ways used by Ptolemy and Alhazen to establish the two modes of refraction (from a less dense medium to a more dense one, and from a more dense medium to a less dense one) and by Ptolemy, Alhazen and Alkindi to establish the equality of the reflection angle with the incidence angle ${ }^{5}$.

${ }^{4}$ Cf. Supra, p. 3. For the case of astronomy named in second place, cf. Laird 1997, p. 268-269.

5 Roger Bacon's Philosophy of Nature. 1983. Oxford, Clarendon Press. part II, chap. 3, p. 110, lines 75-80; chap. 6, p. 138, lines 33-37. See also chap. 7, in which, concerning the burning glasses it is spoken of "demonstration" (p. 148, line 30) and of "proof by 
Bacon states that the two modes of refraction and the law of reflection can be established by experiment (experimentum) using instruments (instrumenta); whence, this type of proof is named also "by instruments". By means of this type of proof it will be perceived by the senses (videbitur ad sensum) how nature works. In the second place, they can be proved by the cause or reason (causa, ratio). In both cases of refraction as well as in the case of reflection, Bacon appeals to the principle of uniformity in the operation of nature, in order to justify the double refraction and the law of reflection ${ }^{6}$. Besides this, in the case of reflection, Bacon presents the geometrical proofs ${ }^{7}$. The third way of proof is named "by effect" (effectus), "by experiment" (experimentum) or "by experience" (experientia). But, it is something different from the first type of proof. Here, indeed, there is something observed (an effect) that is possible or can be understood only if certain ways of the workings of nature are accepted. For example, the combustion (observable) of something placed in the point where the rays of the sun concentrate after being refracted in an spherical crystal, cannot have place or either be understood if it is not admitted that the rays of the sun undergo a double refraction passing from the air to the crystal and, afterwards, from the crystal to the air ${ }^{8}$.

It is possible to observe a parallelism between the reasons presented by Galileo for believing that his definition of uniform accelerated motion embodies the very nature of this one and for posing his postulate about the degree of velocity acquired by heavy bodies in inclined planes having equal heights, with the three ways used by Bacon when treating refraction and reflection. The first reason given by Galileo corresponds to the third procedure of Bacon; the second reason by Galileo recalls the second procedure of Bacon. It is also worth stressing that both, Bacon and Galileo, appeal here to metaphysical axioms: the principle of economy as a law of nature in Galileo, and the principle of uniformity in Bacon 9 . Finally, the experiment used by Galileo to justify his postulate concerning the inclined planes with the same height is similar to the first procedure of Bacon.

Bacon has very probably constructed his scheme of proof, joining the experience with instruments, that he found in Ptolemy and Alhazen, with the double type of demonstration (quia and propter quid) found by him in the Posterior Analytics, where they are linked to the knowledge of the

experience and by effect" (p. 152, line 106).

${ }^{6}$ Roger Bacon's..., part II, chap. 3, p. 114 and chap. 6, p. 140. Cf. Lindberg 1968$-69,32-33$.

7 Roger Bacon's..., part II, chap. 6, p. 141-144.

8 Roger Bacon's..., part II, chap. 3, p. 116-118; chap. 6, p. 144-148; chap. 7, p. 152-154.

9 These two principles imply the idea of finality in the operation of nature. 
cause or reason and to experience (empeiria). Bacon naturally privileges the experience with instruments ${ }^{10}$.

This last type of proof or this way of founding a principle captured the attention at a certain moment in connection with the middle sciences. John Duns Scotus, for example, criticizes Thomas Aquinas for putting the foundation of the principles of these sciences only in a higher science. In this context, he recalls the possibility of foundation by experience and quotes Alhazen:

The subalternated sciences can have some principles, of which they have evidence by experience as Alhazen in the Perspective proofs by experience that the angles of incidence and reflection are equal, even if this can be proved by geometry. Whence, several principles are pure and simply known to the perspectivist, of which, however, he does not know why. If, however, there are in the subalternated, other principles, which are not known by the senses and experience it is necessary that he knows how to reconduct them to other former principles. Therefore, knowledge that only presupposes other principles, not understanding either why of these, nor knowing them by experience, is not science (Reportata Pairisiensia, q. 2, n. 5).

John Pecham also mentions the possibility of establishing the principles of perspective by experience (experimento colligitur et ratione utcumque probatur $)^{11}$. Laird had already quoted a text by Walter Burley that points in the same direction:

The principles of a subalternated science can have evidence and certainty in themselves, so that the subalternated science does not entirely suppose its principles from the higher sciences; so that it need not take them on faith, but declares them a posteriori, that is, through the senses and through experience, as some have said. If this (a posteriori) proof does

10 Bacon also makes a reference to the establishment of principles by experience in the second chapter on the experimental science (part VI) of the Opus majus (v. 2, 172-173). It is possible to identify the three ways of proof used by Bacon in the beginning of book III of Ptolomy's Optics, where he founds the law of reflection. In the edition and translation by A. Lejeune (L'optique de Claude Ptolémée 1989), number [4]-[6] proofs by the effect; numbers [7]-[12], one proof by experiment and beginning by number [14] proofs by reason.

11 Perspectiva communis, II, 160, Proposito 6, 160-161. Cf. Pich 2004, 573-615. Specially, 589, note 69. See also John of Reading. 1989. Scriptum in I Librum Sententiarum, Prologus, q. 6, 94, lins. 15-22; 112, lins. 15-26. 
not suffice for someone refusing to take them on faith, then the higher science must prove them. In brief, then, demonstration in a subalternated science produces knowledge, but it does not produce knowledge as certainly as demonstration in a subalternating science ${ }^{12}$.

Two points stressed by Laird, in his contribution to the volume Method and Order in Renaissance Philosophy of Nature, are certainly very important. First, Galileo was not interested in the problems that occupied for centuries the discussions about the middles sciences. In fact, he was interested in founding his physical-mathematical analysis of motion, for himself and (perhaps mainly) for his contemporaries. For this he used the existing ways, as it is shown in the precedent exposition (cf. Laird 1997, 268-269).

Secondly, Galileo knew very well that an experience can, at best, provide a demonstration that things are so as they are shown by the experience, and not why they are so (quia and propter quid). Then, he went in search, till the end of his life for a demonstration of his postulate about inclined planes, and seems at last to have accomplished this last one (Laird 2001, 255-267, specially 264-267).

Perhaps, it would not be impossible to say that for Galileo, in this issue, what was relevant was not the first book of Posterior Analytics, but the second, where Aristotle was occupied with the principles of science, namely, the definition of the scientific subject and the position of first principles.

To this we could add that, as Laird says (Laird 1997, 269), Galileo was not satisfied with the shaky foundations of "saving the appearances" of his time. So he searched for true and real foundations for his science of astronomy and motion, returning to the Platonic original sense ${ }^{13}$ of "saving the appearances".

12 "Et cum tu quaeris qualiter principia scientiae subalternatae sunt certa, dicendum secundum novum expositorem undecimo Metaphysicae quod principia scientiae subalternatae possunt habere evidentiam et certitudinem ex se ita quod scientia subalternata non omnino supponit sua principia a superiori scientia, sic quod de eis nullam fidem faciat, sed ea declarat a posteriori, scilicet via sensus et experientiae, secundum quod quidam dicunt. Quae probatio, si quantum ad aliquem negantem fidem non sufficiat, tunc scientia superior debet ea probare. Unde breviter, demonstratio in scientia subalternata facit scire, sed non facit scire ita certitudinaliter sicut demonstratio in scientia subalternante" (Quaest. Post., q. 5, ed. Sommers, p. 76-77). Cit. in: Laird 1983, 187, note 37.

13 Smith 1981, 73-99. The author summarizes his content in a subsequent article, "Ptolemy Search for a Law of Refraction: A Case-study in Classical Methodology of 'Saving the Appearances' and its Limitations". 1982, 221-240, specially 224-226. 


\section{A personal note}

I wrote a first article dealing with the introduction to the study of accelerated motion in the Two New Sciences of Galileo, as well as of the presentation of the experience with the inclined plane in 1983 (TRANS/ $F O R M / A C ̧ \tilde{A} O, 6(1983)$, p. 5-12). In this article, I argued that Galileo interpreted the ex hypothesi reason in a realistic manner and that the three schemes of demonstration were used to establish the definition of the accelerated motion, being incompatible with one another. This article was revised in 1991 - "Revisitando três tradições explicativas na lei da queda dos corpos". Revista da Sociedade Brasileira de História da Ciência. 5 (1991), p. 49-52. I accepted the criticism of Marcel Clavelin regarding the interpretation of the ex hypothesi reason and adopted his interpretation of the first scheme of demonstration used by Galileo as being the quia reason, as Crombie and Carugo had established. I also developed further the parallel with Roger Bacon and the sources of this last one. But I continued to refer the three schemes of demonstration to the definition of accelerated motion, to consider only the third scheme as used by the middle sciences and to affirm a certain inconsistence in the use of the three schemes by Galileo.

In 1997, Daniel Di Liscia wrote a review of my book De Tomás de Aquino a Galileo, Campinas: IFCH, Unicamp, 1995, and objected to the parallel between Galileo and Roger Bacon. A second revision was published in 2007 (Dando volta aos problemas - segunda revisitação de "Três tradições explicativas na lei da queda dos corpos". In: Stein, E. (Org.) A cidade dos homens e a cidade de Deus. Porto Alegre: EST Ed., 2007, p. 284-291). This second revision was actually written in 1999. This time I understood that the three patterns of demonstration were used one independently of the other, and so did not pretend a compatibility between them. They are simply three ways for justifying (so I thought) the definition of accelerated motion. But, I continued referring these three schemes to the definition of accelerated motion and suggesting that the third scheme was proper to the middle sciences. In 2004, Roberto Hofmeinster Pich called my attention to the text of Duns Scotus and I began to think about two traditions in the history of middle sciences. One more mathematical (this one would be that of Thomas Aquinas), and one more experimental (of the Franciscans). In this sense, it was also very important a communication by Carolina J. Fernández in the IX Congresso Latino-Americano de Filosofia Medieval - Cf. Fernández, C. J. "Ockham y los Philosophi: la filosofia como descripción contingente de la experiencia". In: De Boni, L. and Pich, R. H. (Orgs.). A recepção do pensamento Greco-romano, árabe e judaico pelo Ocidente Medieval. Porto Alegre: Edipucrs, 2004, p. 657-668. 
Finally, I read the two articles by W. R. Laird and it seems to me that things now fit better in their places.

\section{Bibliography}

Clagett, M. 1951. The Science of Mechanics in the Middle Ages. Madison: The University of Wisconsin Press.

Clavelin, M. 1986. A revolução galileana: revolução metodológica ou teórica. Cadernos de História e Filosofia da Ciência 9, 35-44.

Galilei, Galileu. 1929-1939. Discorsi e dimonstrazioni matematiche intorno a due nuove scienzie. In: A. Favaro (org.). Le opera di Galileu Galilei. Edizione. Nazionale. $2^{\mathrm{a}}$ ed. Florença: G. Barbera, v. 8.

John Duns Scotus. 1891-1895. Reportata Parisiensia. In: Opera Omnia. Paris: Vivès, v.22.

John of Reading. 1989. Scriptum in I Librum Sententiarum. Ed. Livesey, Leiden: E. J. Brill.

Laird, W. R. 1983. The Scientiaes Mediae in Medieval Commentaries on Aristotle's Posterior Analytics. (PhD Dissertation).

Laird, W. R. 1997. Galileo and the Mixed Sciences. In: Di Liscia, D.A.; Kessler, E. and Methuen, C. Method and Order in Rennaissance Philosophy of Nature. Andershot: Ashgate.

Laird, W. R. 2001. Renaissance Mechanics and the New Science of Motion. In: Montesinos, J. and Solís, C. Largo Campo di Filosofare. Eurosymposium Galileo 2001. Canarias: Fundación Canaria Orotava de Historia de la Ciencia, 255-267.

Lindberg, D. C. 1968-69. The Cause of Refraction in Medieval Optics. The British Journal for the History of science 4, 23-38.

Pich, R. H. 2004. Subordinação das ciências e conhecimento experimental. In: De Boni, L. A. e Pich, R. H. (Orgs.). A recepção do pensamento Greco-romano, árabe e judaico pelo Ocidente medieval. Porto Alegre: Edipucrs, 573-615.

Ptolemy. 1989. L'optique de Claude Ptolémée. Edition and translation by A. Lejeune. Leiden: E. J. Brill.

Roger Bacon. 1983. Roger Bacon's Philosophy of Nature. Critical edition, translation, introduction and notes by Lindberg, D. C. Oxford: Clarendon Press.

Roger Bacon. 1964. Opus majus. Ed. J. Henry Bridges. Frankfurt: G.m.b.H. reprint.

Roger Bacon. 1996. Perspectiva communis. Ed. David C. Lindberg. Oxford: Clarendon Press. 
Smith, A. M. 1981. Saving the Appearances of the Appearances: The Foundation of Classical Geometrical Optics. Archive for History of Exact Sciences 24, 73-99.

Thomas Aquinas, 1962 Summa Theologiae. Roma: Editiones Paulinae.

Wallace, W. A. 1992. Galileo's Logic of Discovery and Proof. In: Boston Studies in the Philosophy of Science. Boston: Dordrecht. 